\title{
POSSIBLE MECHANISMS OF CADMIUM FETOTOXICITY IN GOLDEN HAMSTERS AND MICE: UPTAKE BY THE EMBRYO, PLACENTA AND OVARY
}

\author{
LENNART DENGKER \\ Department of Toxicology, University of Uppsala, \\ Biomedical Centre, Box 573, S-751 23 Uppsala, Sweden
}

(Received 18th November 1974)

\begin{abstract}
Summary. Pregnant golden hamsters and mice of different gestational ages were injected intravenously with ${ }^{109} \mathrm{CdCl}_{2}$. The whole animal or the uterus and embryos were submitted to autoradiography. Cadmium administered on the 8th day accumulated in the primitive gut of the embryos. No cadmium was detected in the embryos after administration on or after the 9th day (hamster) and 11th day (mouse). This finding can be explained by the ability of cadmium to pass from the yolk-sac cavity into the primitive gut (where it is absorbed) before the closure of the vitelline duct but not later. This uptake by the embryo might explain the severe malformations produced by cadmium given on the 8th day as compared with the 9 th day in the hamster. Cadmium is also heavily accumulated in the decidua (mainly the antimesometrial part), the yolk sac, the ectoplacental cone, and later in the chorioallantoic placenta-possibly disturbing the maternal-embryonic relationship and fetal nutrition. A high accumulation in the GL and the follicles and in the pituitary may also disturb reproductive function.
\end{abstract}

\section{INTRODUCTION}

The biological effects of cadmium deserve attention for many reasons. Its use in different industrial processes and products has increased its presence in the environment. Its exceptionally long half-life in the human body, about 30 years (Kjellström et al., 1971), stresses the importance of a better understanding of its action. Cadmium exerts specific effects in the body, e.g. on the steroid producing organs (Pař́zek, 1957; Kar et al., 1959; Kaul \& Ramaswami, 1970). In late gestation, it causes placental necrosis, especially in the pars fetalis, and subsequent fetal death (Pařizek, 1964). In the mother, it causes pathological changes with clinical and morphological similarities to human toxaemia of pregnancy (Pařízek, 1965).

In the golden hamster during early gestation (8th to 9th day), cadmium causes resorptions and embryonic structural defects, the character of which is dependent on the time of administration (Ferm \& Carpenter, 1967; Ferm, 1971; Gale \& Ferm, 1973). These authors thought that cadmium was an 
embryonic "site-specific teratogen" due to its interference with specific enzymatic reactions. In the rat (Barr, 1973; Scharpf et al., 1972) and in the mouse (Schroeder \& Mitchener, 1971), malformations and fetal death are produced by cadmium.

A whole-body autoradiographic study in the mouse during late gestation revealed no fetal uptake of radioactive cadmium (Berlin \& Ullberg, 1963), but Ferm et al. (1969) showed that small amounts of radioactive cadmium reached the fetus at the time of embryogenesis (8th to 9th day) in the golden hamster. Lucis et al. (1971) showed that small amounts of cadmium passed the placenta during the first third of gestation in the rat, and Chaube et al. (1973) found hardly detectable amounts in human fetuses of different ages.

This investigation was undertaken to study the possible accumulation of cadmium in embryonic (fetal) and placental structures and also in the whole maternal genital apparatus in mice and golden hamsters at different stages of gestation.

\section{MATERIALS AND METHODS}

\section{Isotope}

Carrier-free ${ }^{109} \mathrm{CdCl}_{2}$ (sp. act. $95 \mu \mathrm{Ci} / \mu \mathrm{g}{ }^{109} \mathrm{Cd}$ ) was obtained from The Radiochemical Centre Amersham, England, dissolved in $0.1 \mathrm{M}$-hydrochloric acid $\left(2 \mu \mathrm{g}{ }^{109} \mathrm{Cd} / \mathrm{ml}\right)$. This was diluted with distilled water so that $0.053 \mathrm{M}$ hydrochloric acid contained $100 \mu \mathrm{Ci}$, or $1.05 \mu \mathrm{g}{ }^{109} \mathrm{Cd} / \mathrm{ml}$ before injection.

\section{Animals}

Four golden hamsters (Mesocricetus auratus) and ten mice (G57BL and NMRI) were used in this study. The animals were maintained on a complete pellet diet (Anticimex: Sollentuna, Sweden) at a room temperature of $25^{\circ} \mathrm{C}$ and were allowed free access to water. The injection schedule is shown in Table 1.

Golden hamsters. Golden hamsters, weighing about $110 \mathrm{~g}$, were mated between 19.00 and 21.00 hours, and the next day was designated the first day of gestation. On the 8 th day at 10.00 hours, three animals received an intravenous injection into a femoral vein under light ether anaesthesia. One was allowed to survive for $4 \mathrm{hr}$, another for $24 \mathrm{hr}$ and the third for 4 days. On the 9th day at 13.00 hours, one animal received a similar injection and was killed after $4 \mathrm{hr}$. All animals received $20 \mu \mathrm{Ci}{ }^{109} \mathrm{CdCl}_{2}$, equal to $0.21 \mu \mathrm{g}{ }^{109} \mathrm{Cd}$. After different survival times, the animals were killed by prolonged ether anaesthesia. The abdomen was opened and the uterus, ovaries, oviducts and cervix were removed. The uterus was then placed in a horizontal plane on a microtome stage, embedded in an aqueous gel of carboxymethylcellulose (GMC) and frozen by immersion of the stage in a mixture of solid carbon dioxide and hexane $\left(-78^{\circ} \mathrm{C}\right)$. To estimate the relative uptake in the uterus and the embryos in relation to other maternal organs, pieces of the liver and kidney (known to accumulate cadmium) were removed and embedded in the CMC together with the uterus. The hamster killed after 4 days (injected on the 8th day) was embedded intact in the $\mathrm{CMC}$ and frozen as described above. According to the method of Ullberg (1954, 1958), sagittal $10 \mu \mathrm{m}$ and $20 \mu \mathrm{m}$ sections, attached to tape (No. 800, 
Minnesota Mining and Manufacturing Co.), were cut in a microtome at $-15^{\circ} \mathrm{C}$ through the frozen animal or uterus (in a horizontal plane through as many embryos as possible) and were dried at the same temperature. The dried sections were then transferred to room temperature. Exposure was achieved by apposition against roentgen film (Industrex G: Kodak). The exposure time ranged from 10 to 50 days. Selected sections were stained with haematoxylin and eosin and mounted on glass slides in Euparal (Flatters \& Garnett Ltd, Manchester, England) under a coverslip.

Mice. Mice, weighing about $25 \mathrm{~g}$, were mated overnight. The presence of a vaginal plug in the morning was taken to indicate conception, and the day was called Day 1 of gestation. On the 8th day, six mice (NMRI) received an intravenous injection of $10 \mu \mathrm{Ci}$ or $0.1 \mu \mathrm{g}{ }^{109} \mathrm{Cd}$ into the tail vein. One animal was killed by prolonged ether anaesthesia on the 9 th, 11th, 13th, 15th, 17th and 19th day of gestation. Two mice (C57BL) were injected intravenously with 5 $\mu \mathrm{Ci}$ or $0.05 \mu \mathrm{g}{ }^{109} \mathrm{Cd}$ on the 11 th day of gestation and were killed after $8 \mathrm{hr}$ and 8 days, respectively. One mouse (C57BL) received $5 \mu \mathrm{Ci}$ or $0.05 \mu \mathrm{g}{ }^{109} \mathrm{Cd}$ on the 16 th day of gestation and was killed $4 \mathrm{hr}$ later. One non-pregnant mouse (NMRI), which received $10 \mu \mathrm{Ci}$ or $0.1 \mu \mathrm{g}{ }^{109} \mathrm{Cd}$ and was mated 35 days later, was killed on the 19th day of gestation ( 53 days after the injection). In the series of mice injected on the 8th day, the uteri, ovaries and oviducts were removed as described above. In the mouse injected on the 11 th day and killed $8 \mathrm{hr}$ later and that injected on the 16th day and killed $4 \mathrm{hr}$ later, only half the uterus was removed and the mother's abdominal wall was then sutured. Thereafter, these mothers were used intact. The uteri and/or the whole animals were embedded in CMC, frozen and submitted to autoradiography as described above for the golden hamsters.

\section{RESULTS}

The overall distribution of cadmium in hamsters and mice was essentially the same, and was in accordance with that described by Berlin \& Ullberg (1963). The most prominent accumulation was seen in the liver and the renal cortex. The findings concerning the embryonic (fetal) uptake are summarized in Table 1 .

\section{Golden hamsters}

Embryonic accumulation. There was a marked variation with time in the embryonic uptake of cadmium. In the embryos of the animals injected on the 8th day of gestation, a considerable accumulation was seen both 4 and $24 \mathrm{hr}$ later in a structure which seemed to represent the primitive gut (PI. 1, Figs 1 and 2; Pl. 2, Figs $3 \mathrm{a}$ and $3 \mathrm{~b}$ ). Radioactivity was still seen in the gut 4 days after the injection. No radioactivity was seen in any other embryonic structure. The injection on the 9th day did not result in any embryonic uptake (Pl. 3, Figs 4a and $4 \mathrm{~b})$.

This structure was continuous with the yolk-sac endoderm (Pl. 2, Figs 3a and $3 \mathrm{~b}$ ) from which the gut is developed as a pocket; the structure seemed to be extended longitudinally as it could be seen both in the cranial and the caudal 
parts of the 9-day-old embryo (24 hr survival time) (Pl. 2, Figs 3a and b) ; in cross sections of the structure its tubular form was often clearly discerned (Pl. 1, Fig. 2).

Placental accumulation. Four hours after the injection on the 8th day of gestation, a heavy accumulation of ${ }^{109} \mathrm{Cd}$ was observed in the yolk sac and in the ectoplacental cone (Pl. 1, Fig. 1). The antimesometrial decidua had a moderate

\section{EXPLANATION OF PLATES}

All figures are based on autoradiography of sections of uteri or whole bodies of golden hamsters or mice after the intravenous injection of ${ }^{109} \mathrm{CdCl}_{2}$. The radioactivity is sometimes represented by black grains superimposed on the sections, and sometimes by white areas in a copy of the autoradiogram coupled with a photograph of the section on the same Plate. All sections were stained with haematoxylin and eosin. $\mathrm{A}=$ amnion, $\mathrm{B}=$ brain, $\mathrm{Ch} \mathrm{Pl}=$ chorioallantoic placenta, $\mathrm{CL}=$ corpus luteum, $\mathrm{CO}=$ cumulus oophorus, $\mathrm{DA}=$ antimesometrial decidua, $\mathrm{DB}=$ decidua basalis, $\mathbf{E}=$ embryo, $\mathrm{F}=$ follicle, $\mathrm{G}=$ gut, $\mathrm{MB}=$ maternal blood, Mes = mesovarium, $\mathrm{NT}=$ neural tube, $\mathrm{O}=$ ovum, $\mathrm{Pl} \mathrm{C}=$ ectoplacental cone, $\mathrm{U}=$ uterine wall, $\mathrm{VD}=$ vitelline duct, $\mathrm{YS}=$ visceral yolk sac.

\section{PLATE 1}

FIG. 1. Photomicrograph of a section with the superimposed autoradiogram (black grains representing radioactivity). The uterus of a hamster $4 \mathrm{hr}$ after the injection on the 8 th day of gestation, showing one embryo. Note the high uptake in the primitive gut, the visceral yolk sac and in the ectoplacental cone. $\times 17$.

FIG. 2. Photomicrograph of a section with the superimposed autoradiogram (black grains). A hamster uterus $24 \mathrm{hr}$ after the injection on the 8 th day of gestation, showing an embryo. Note the accumulation in the gut wall of the embryo and in the visceral yolk sac. $\times 17$.

\section{PLATE 2}

Fig. 3. Detail of (a) an autoradiogram and (b) the section of a hamster uterus, showing an embryo, $24 \mathrm{hr}$ after the injection on the 8th day. The U-shaped embryo is cut in a way that gives two transverse planes of the body at different levels. Note that there is an accumulation in the gut at both levels. Note also the accumulation that can be seen in the visceral yolk sac continuing into the vitelline duct and the gut. $\times 17$.

\section{PLATE 3}

Fig. 4. (a) Autoradiogram and (b) section of a whole uterus of a hamster $4 \mathrm{hr}$ after the injection on the 9 th day. The embryos are cut at different levels. No radioactivity can be seen in the embryos. There is however a heavy accumulation in the ectoplacental cone, and the visceral yolk sac. $\times 3.4$.

\section{PLATE 4}

FIG. 5. Detail of autoradiogram of a hamster ovary $4 \mathrm{hr}$ after the injection on the 8th day. Note the high uptake in the CL, the follicular walls and lower in the interstitium. $\times 17$.

Fig. 6. Detail of (a) autoradiogram with (b) the section of a hamster ovary $24 \mathrm{hr}$ after the injection on the 8th day. There is an accumulation in the CL and the follicles but the cumulus oophorus and the ovum are almost devoid of radioactivity. $\times 14$.

Fig. 7. (a) Autoradiogram and (b) section of a mouse uterus $8 \mathrm{hr}$ after the injection on the 11 th day. Note that the embryos are free of radioactivity. The decidua surrounding the fetus, the antimesometrial decidua, the visceral yolk sac and the ectoplacental cone have accumulated the cadmium. $\times 6$.

\section{PLATE 5}

FIG. 8. Autoradiogram of a whole-body section of a mouse $4 \mathrm{hr}$ after the injection on the 16 th day of gestation. Note the absence of radioactivity in the fetuses but the heavy accumulation in the chorioallantoic placentae (comparable with that in the liver and kidney). The pituitary and adrenal cortex also show uptake.

FIG. 9. (a) Autoradiogram and (b) whole body section of a mouse on the 19th day of gestation. It was injected 35 days before coitus. Note the very weak uptake in the placentae and the absence of cadmium in the fetuses. There is a considerable accumulation in the pituitary, the thyroid and in the ovarian interstitium. 

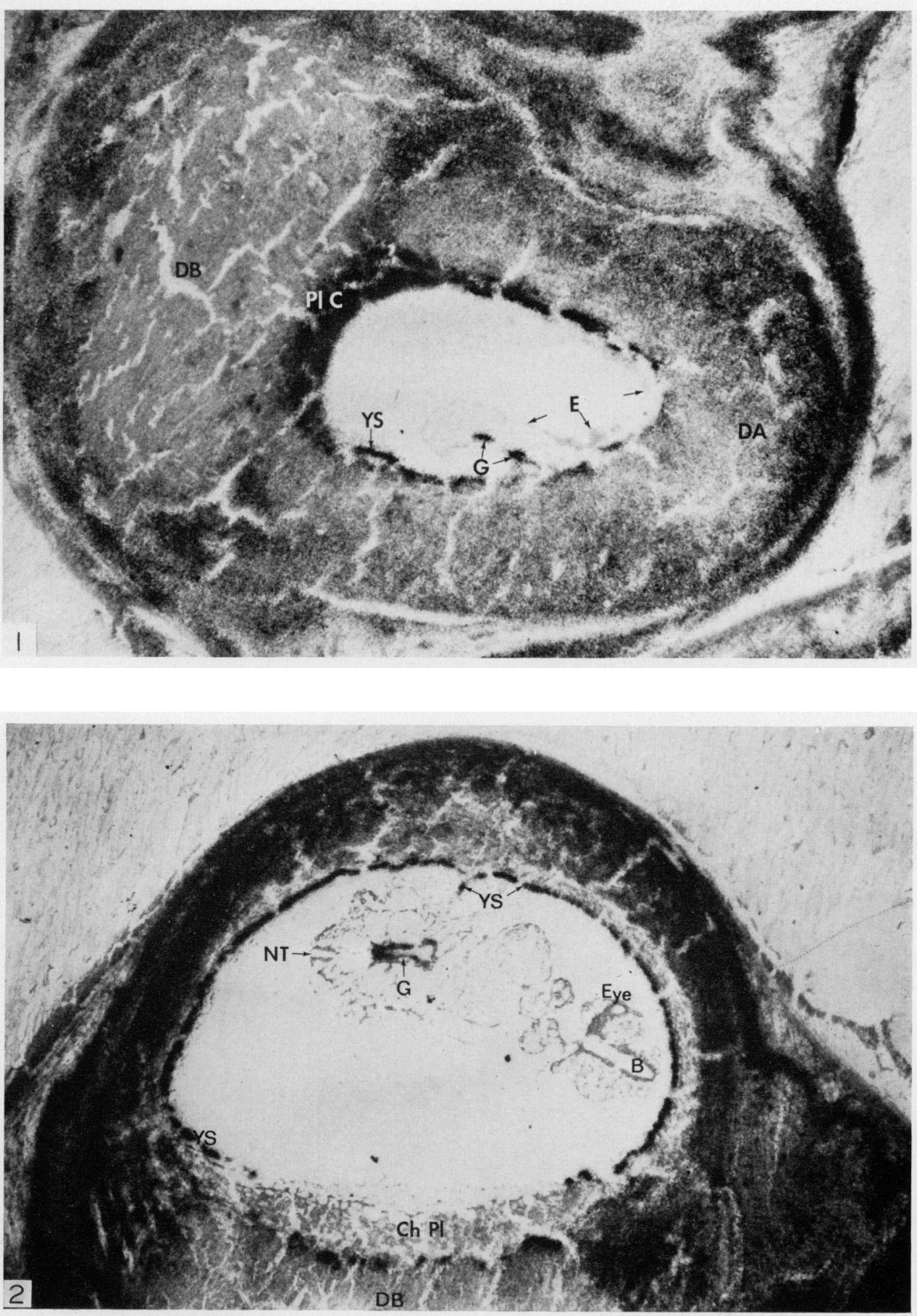

(Facing p. 464) 


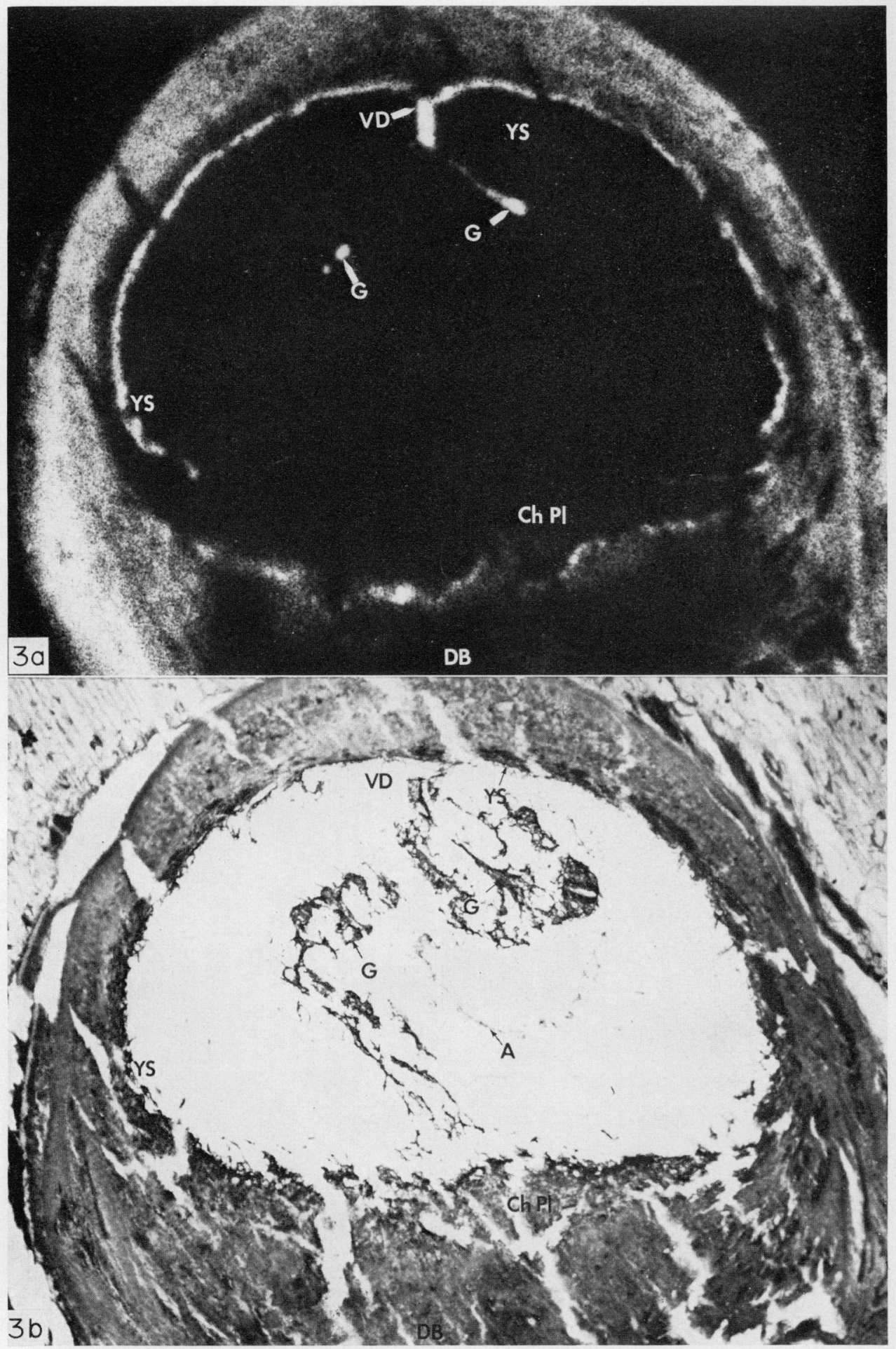



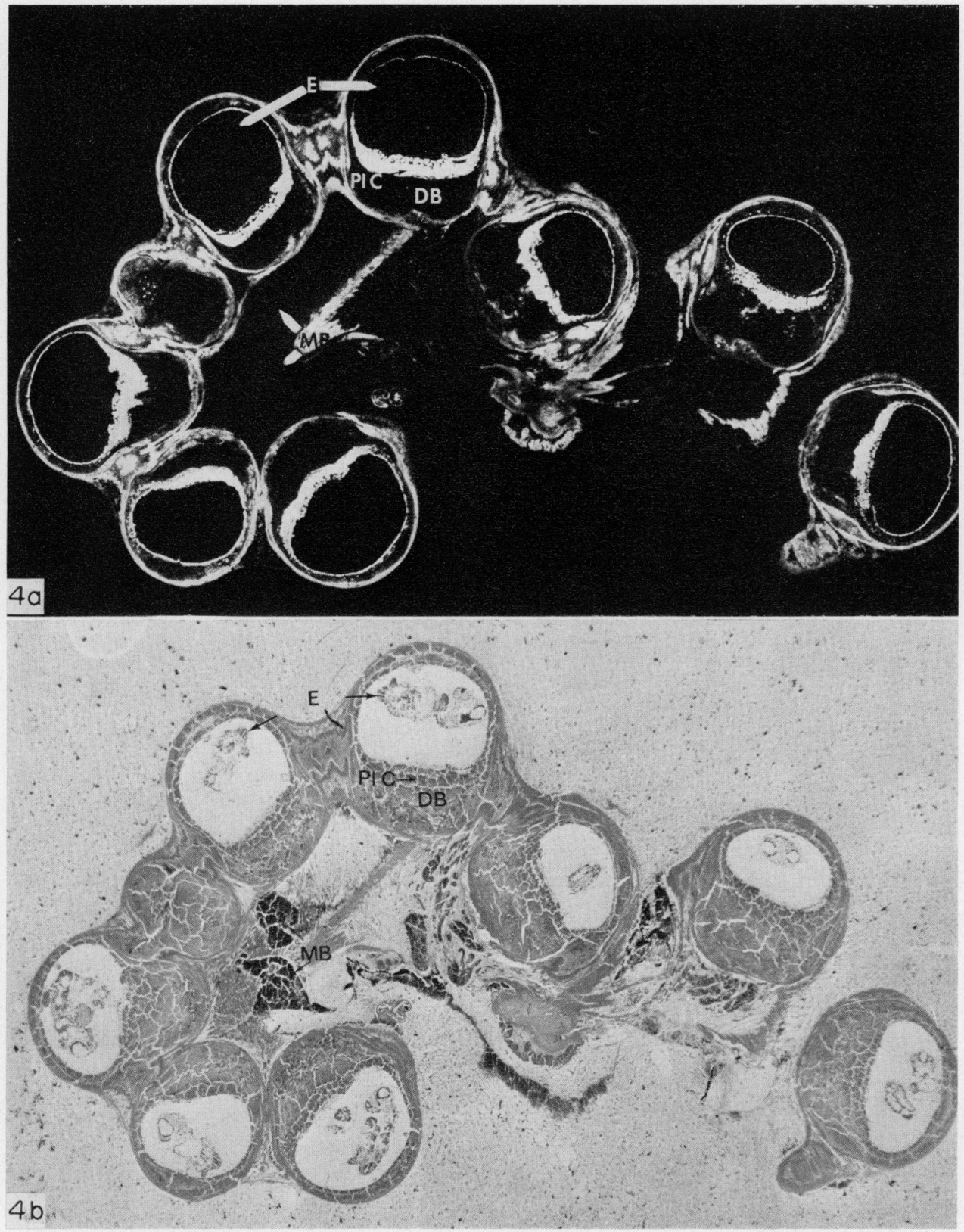

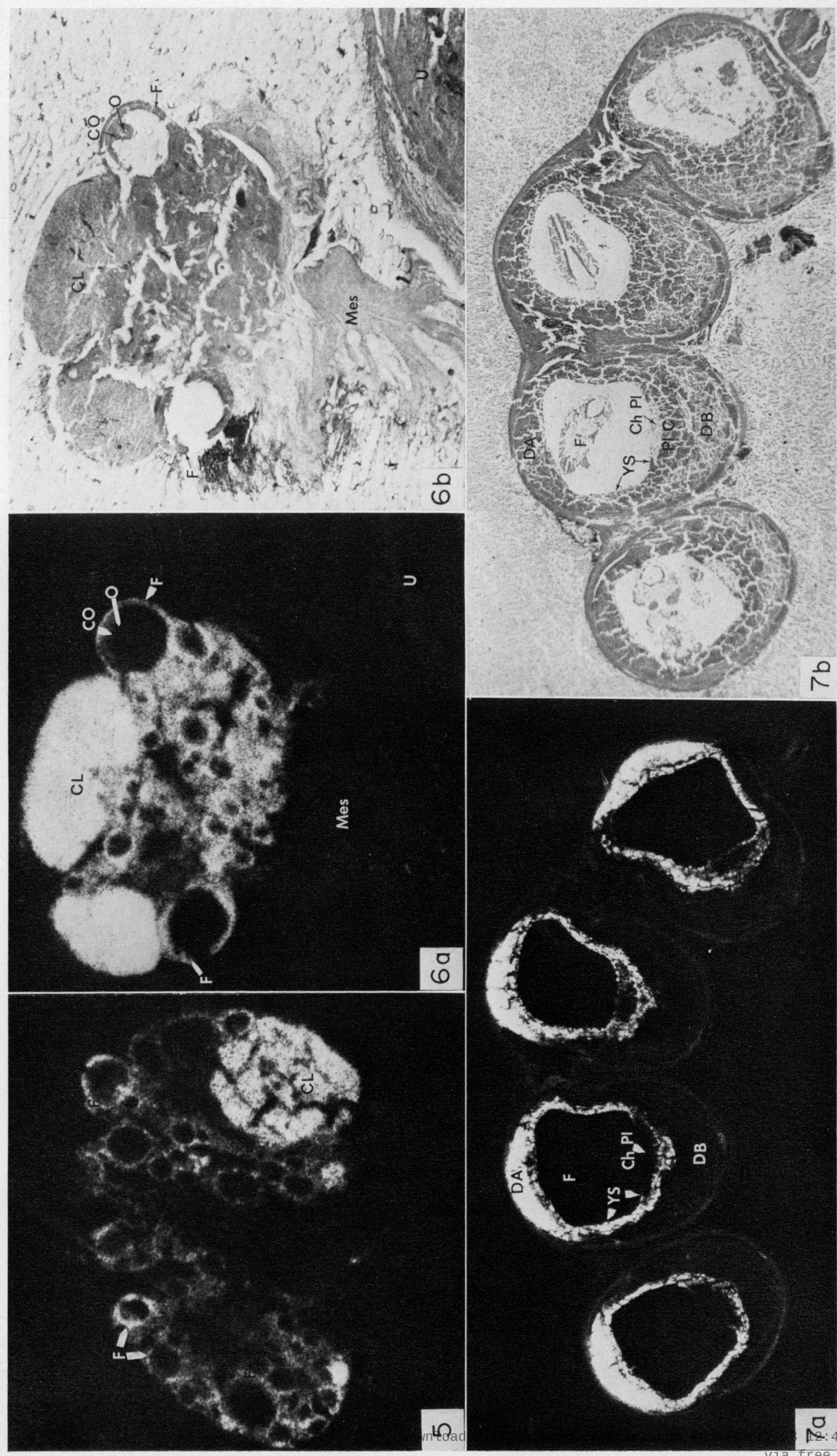
PLATE 5

\section{Pituitary}

\section{Adrenal Kidney Placentae}

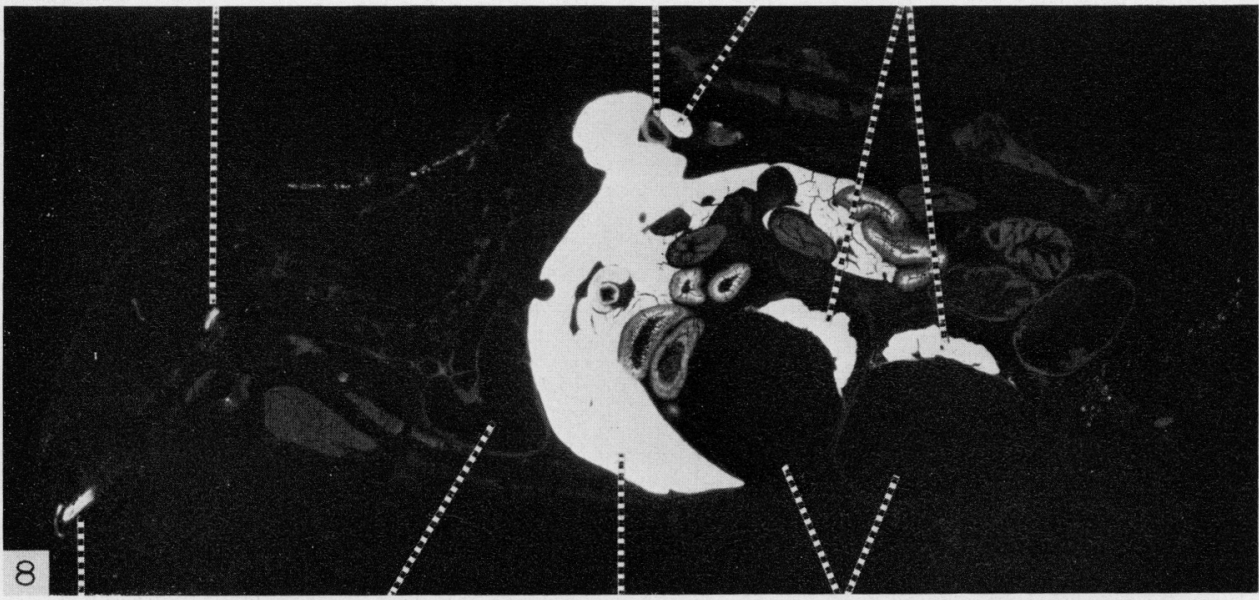

Tooth

Blood of heart

Liver

Fetuses

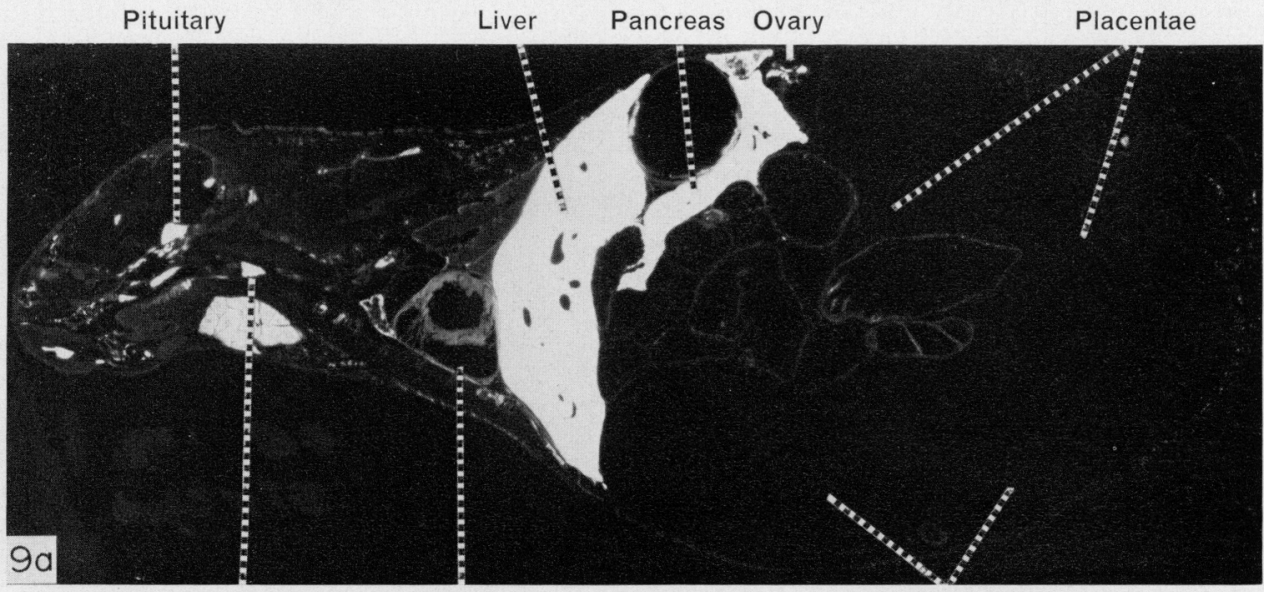

Thyroid

Blood of heart

Fetuses

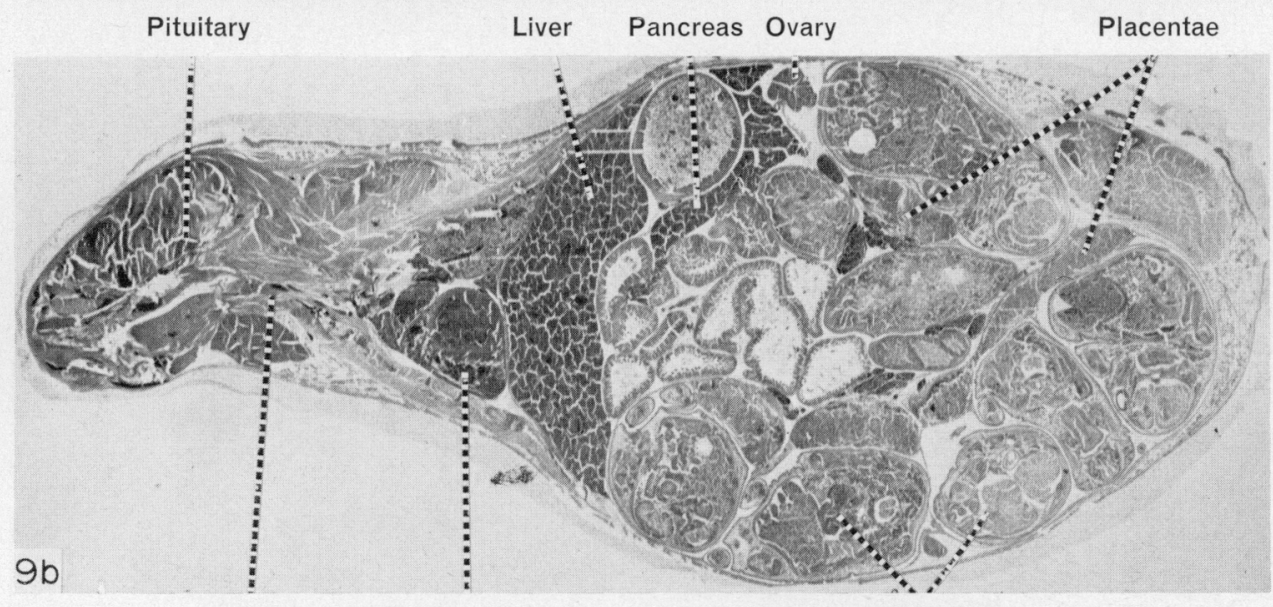

Thyroid

Blood of heart

Fetuses 
Table 1. Injection regimen of ${ }^{109} \mathrm{CdCl}_{2}$ into pregnant golden hamsters and mice and the main subsequent distribution in the embryos and placentae

\begin{tabular}{|c|c|c|}
\hline $\begin{array}{l}\text { Day of gestation on } \\
\text { which }{ }^{109} \mathrm{Cd} \text { injected }\end{array}$ & $\begin{array}{l}\text { Interval between } \\
\text { injection and autopsy }\end{array}$ & $\begin{array}{l}\text { Main area } \\
\text { of uptake }\end{array}$ \\
\hline \multicolumn{3}{|l|}{ Hamster } \\
\hline 8 & $4 \mathrm{hr}$ & Embryonic gut \\
\hline 8 & $24 \mathrm{hr}$ & Embryonic gut \\
\hline 8 & 4 days & Embryonic gut \\
\hline 9 & $4 \mathrm{hr}$ & No embryonic uptake \\
\hline \multicolumn{3}{|l|}{ Mouse } \\
\hline 8 & \multirow{5}{*}{$\begin{array}{c}24 \mathrm{hr} \\
3 \mathrm{days} \\
5,7,9 \text { or } \\
11 \text { days } \\
8 \mathrm{hr} \\
8 \mathrm{days} \\
4 \mathrm{hr}\end{array}$} & \multirow{2}{*}{$\begin{array}{l}\text { Embryonic gut } \\
\text { Traces in the embryo }\end{array}$} \\
\hline $\begin{array}{l}8 \\
8\end{array}$ & & \\
\hline \multirow{4}{*}{$\begin{array}{l}11 \\
11 \\
16\end{array}$} & & \multirow{2}{*}{ No embryonic uptake } \\
\hline & & \\
\hline & & No embryonic uptake \\
\hline & & $\begin{array}{l}\text { Accumulation in } \\
\text { chorioallantoic }\end{array}$ \\
\hline 19 & 53 days & $\begin{array}{l}\text { placenta } \\
\text { No uptake in embryo }\end{array}$ \\
\hline & & or placenta \\
\hline
\end{tabular}

Each survival time is represented by one animal.

concentration. A high concentration of ${ }^{109} \mathrm{Cd}$ was still present in the yolk sac $24 \mathrm{hr}$ after the injection. In the developing chorioallantoic placenta, the concentration was low, but at its junction with the decidua basalis activity was seen in the cells of the ectoplacental cone (Pl. 1, Fig. 2; Pl. 2, Figs 3a and 3b). By 4 days after injection (12 days of gestation), the ${ }^{109} \mathrm{Cd}$ concentration was low in all the placental structures. On the 9 th day of gestation, $4 \mathrm{hr}$ after the injection of cadmium, a high concentration was noted in the yolk sac and the ectoplacental cone and a moderate concentration in the developing chorioallantoic placenta (PI. 3, Figs 4a and 4b).

Ovarian accumulation. At $4 \mathrm{hr}$ (Pl. 4, Fig. 5) and $24 \mathrm{hr}$ (Pl. 4, Figs 6a and 6b) after the injection, there was a heavy accumulation of cadmium in the CL and in the thecal cells of the follicles, and a lighter accumulation in the granulosa cells and the interstitium. Four days after the injection (12th day of gestation), there was still a high concentration in the GL, while it was somewhat lower in the follicular walls. In the interstitium, areas (possibly atretic follicles) with a high cadmium content were seen.

\section{Mice}

Embryonic accumulation. In the series of mice injected on the 8th day of gestation, embryonic uptake was seen $24 \mathrm{hr}$ later even if it was not always of the magnitude observed in the hamster. Radioactivity was still noted in some embryos 3 days after injection. At 5, 7,9 and 11 days after injection, no fetal cadmium was seen. The localization was the same as that described for the golden hamsters. In the two mice injected at the 11 th day of gestation that were allowed to survive for $8 \mathrm{hr}$ (Pl. 4, Figs $7 \mathrm{a}$ and $7 \mathrm{~b}$ ) and 8 days, respectively, no embryonic uptake was observed. The same was true for the mouse injected on the 16th day 
of gestation that was killed $4 \mathrm{hr}$ later (Pl. 5, Fig. 8) and the mouse injected 35 days before mating and killed on the 19th day of gestation (53 days survival time) (Pl. 5, Figs 9a and 9b).

Placental accumulation. There was a heavy accumulation of ${ }^{109} \mathrm{Cd}$ in the decidua in the antimesometrial part of the uterus of the mice injected on the 8th day of pregnancy. This was maximal $24 \mathrm{hr}$ after injection and then gradually diminished so that in the animals killed at a late stage of gestation, only spots of radioactivity were noted in this part of the uterus. There was also some uptake in the yolk sac. Injection on the 11th day of gestation ( $8 \mathrm{hr}$ survival time) resulted in an antimesometrial accumulation and also occurred in the circumference of the fetus, apparently in the omphalopleure and in the decidua capsularis adjacent to it (Pl. 4, Figs 7a and 7b). The placental cone and the yolk sac also showed a considerable accumulation. Eight days later, spots of radioactivity were seen in the decidua basalis, sometimes surrounding the maternal blood vessels, and in the uterine wall. In the mouse injected at the 16th day of gestation and killed $4 \mathrm{hr}$ later, there was a heavy accumulation of ${ }^{109} \mathrm{Cd}$ in the placental labyrinth (Pl. 5, Fig. 8) which was comparable to the concentration in the maternal liver. In the decidua basalis, spots of cadmium uptake were seen as in the mouse killed on the 19th day of gestation. In the mouse injected 35 days before mating (PI. 5, Figs $9 \mathrm{a}$ and $9 \mathrm{~b}$ ) the placental and uterine concentrations were very low. In contrast to the decidua, however, the placental labyrinth showed a weak uptake.

Ovarian accumulation. As in the hamster, the injection of cadmium into the mouse resulted in an ovarian accumulation, although it was not equally marked. In all mice, at short survival intervals (up to $24 \mathrm{hr}$ ), there was moderate concentration in the GL and in the follicular walls. Three days after injection, there was still some radioactivity in these structures. Later, areas of high concentration (possibly atretic follicles) were seen in the interstitium. In the mouse which was killed after 53 days (Pl. 5, Figs $9 \mathrm{a}$ and $9 \mathrm{~b}$ ), a high concentration was still seen in the interstitium.

Pituitary. In the hamster and the mouse, there were marked accumulations of cadmium in the pituitary (Pl. 5, Figs $8,9 a$ and $9 b$ ).

\section{DISCUSSION}

\section{Embryo}

The present investigation showed that cadmium passed to the embryo and strongly accumulated in the primitive gut only when injected before a certain stage of gestation, after which there was essentially no uptake. The modified whole-body autoradiographic technique used (the removal of the uteri) allowed the taking of thin and even sections. All embryos could be represented at the same section and all embryonic and placental structures could be seen and identified if many sections were taken. In late pregnancy when the fetuses are larger, the whole pregnant animal can be easily investigated. At this stage, the fetal-maternal relationships in the distribution of cadmium are of interest.

Extensive whole-body autoradiographic studies in our department have shown that most chemicals reach the fetus in late pregnancy, although there is 
a wide range in the degree of uptake (Ullberg, 1972; Dencker \& Ullberg, 1973). The exceptions include a few radioelements, among them cadmium (Berlin \& Ullberg, 1963), which did not appear in the fetus in detectable amounts. The behaviour of cadmium contrasts markedly to that of another teratogen, 2,4,5-T, that reached rather high concentrations in the late-stage fetus but was only found in traces in the early embryo (Lindquist \& Ullberg, 1971). It has been shown in the rabbit that Evans blue attached to maternal serum proteins can be detected in the yolk-sac cavity by the 7th to 8 th day of gestation (Brambell \& Hemmings, 1949). The subcellular structure of Reichert's membrane and the parietal yolk-sac endoderm in the rat (Days 7 to 10 ) shows that serum proteins may pass through these membranes into the yolk-sac cavity (Merker \& Villegas, 1970). This is probably true also for the golden hamster and the mouse due to the similarities in the formation of these embryonic membranes. In mice, a short time after the administration of a single dose, cadmium was found in the serum fractions corresponding to the size of albumin or the larger proteins (Nordberg, 1972). The ion may be transferred into the yolk-sac cavity bound to such proteins. The high uptake found in the visceral yolk-sac endoderm also favours such a transfer; cadmium (probably bound to proteins) had been absorbed by this endodermal tissue from the yolk-sac cavity.

In the early postimplantation stages, there is free communication between the primitive gut and the yolk-sac cavity, which makes the passage of yolk-sac material into the gut lumen possible, after which it can be absorbed by the gut endoderm. During Days 8 and 9 of gestation, both in the mouse and the hamster, the considerable structural development of the embryo results in the closure of this communication. This has been shown to be completed 9 to $9 \frac{1}{4}$ days after coitus in the hamster (Boyer, 1953). It is probable that this communication had functionally disappeared at the time of injection on the 9 th day in the hamster in this investigation. In the mouse, this so-called 'vitelline duct' is closed $9 \frac{1}{2}$ days after conception (Rugh, 1968) so that it must have been totally closed in the mice injected on the 11th day. Agreement thus seems to exist between the degree of communication through the vitelline duct and the observed uptake in the gut wall.

It is clearly seen in the autoradiograms and it is notable that, even $24 \mathrm{hr}$ after the injection (on the 8th day) in the hamster, there was a selective accumulation and retention in the gut wall but no radioactivity was observed in any other organ. From different parts of the primitive gut, many essential organs are formed by the interaction of the surrounding mesenchyme; the Eustachian tube, palatine tonsils, thyroid and parathyroid glands, thymus, lungs, liver and pancreas. Endodermal damage by the accumulation of cadmium may hinder the normal formation and differentiation of these organs and the digestive tract, but the teratogenic effect of cadmium on these organs requires further investigation.

The cadmium damage to structures of mesodermal origin, e.g. bone structures (Gale \& Ferm, 1973), is more difficult to explain on the basis of an endodermal accumulation. It seems possible, however, that long-term retention in the gut wall may affect intestinal function with secondary damage to all the organism. The role of the intestine in early intrauterine life is not well known. 
In human fetuses, the gut is already opened to the stomodaeum by the end of the 3rd week (Langman, 1969) and at 6 to 7 weeks muscles and nerves are seen in the gut wall (Becker et al., 1940). Fetal swallowing has been observed at 12 weeks of age (Mori, 1956) and at mid-pregnancy (Abramovich, 1970). Intestinal lysosomal activity in 10-week-old embryos is the same as after birth (Antonowicz et al., 1974). As the gut endoderm is derived from the visceral yolk-sac endoderm, it seems probable that these two structures develop the same role for the absorption of nutrients to the fetus (the yolk sac mainly in rodents) from the amniotic, and the uterine cavities, respectively. It is tempting to interpret the resorptions and malformations, especially facial ones, recorded by Ferm (1971) and Gale \& Ferm (1973), after the administration of cadmium on the 8th day as compared with the 9th day, as a consequence of a difference in transfer to the embryo. This may indicate a direct effect on the embryo. This finding is of more fundamental interest in that the same transport route into the embryo may be utilized by other substances of teratogenic importance, and also those which are blocked by the placenta during later gestational stages. In man, a communication persists between the yolk-sac cavity and the primitive gut up to about 1 month (Langman, 1969). As the yolk sac is large (and probably functionally important) during the first weeks of pregnancy, these experimental findings may also have some relevance in man.

\section{Decidua and placentae}

The observed variation in sensitivity to teratogens can also be a function of the stage of development (see e.g. Degenhardt \& Kleinebrecht, 1971), and therefore extra-fetal mechanisms may also be responsible. Many cations, among them cadmium, bind to the thiol groups on enzymes which are essential for their activity (Hewitt \& Nicholas, 1963). Cadmium is also known to inhibit many enzymes (Kench \& Gubb, 1970; Unger \& Clausen, 1973). Progesterone induces a growth of the endometrium and a change in its enzyme content preparatory to implantation (Hafez, 1964). Histochemical methods have shown the presence of proteolytic enzymes in the antimesometrial decidua on the 8th day in the mouse (Bergström, 1972), the localization of which was in accordance with that of cadmium in the mouse on the 8th day in the present investigation. A possible enzyme affinity for cadmium may influence the maternal-embryonic relationship, and result in inhibited implantation, resorption or malformations.

The visceral yolk sac has an essential role in the nutrition of the early embryo and the well-known teratogen, trypan blue, is believed to act by inhibiting this nutrition (see e.g. Lloyd \& Beck, 1969). The accumulated cadmium may also disturb vital enzyme systems in this structure. In the chorioallantoic placenta during late gestation in the mouse, there was a heavy accumulation of cadmium which was as high as that in the liver and kidney. This uptake may be related to the numerous placental enzymes (Hafez, 1964) which would explain the extensive placental necrosis with the subsequent fetal death caused by cadmium which has been observed in the structurally related rat placenta in late gestation (Pařizek, 1964). Mice injected 35 days before coitus had very low concentrations of cadmium in the late-stage placenta, indicating an insignificant release from the other organs. This diminishes the risk of fetal damage by cadmium 
accumulated in the mother before gestation. This finding is in accordance with that of Webb (1972).

In connection with the accumulation of cadmium in the steroid-producing organs, i.e. the interstitial parts of the testes (Berlin \& Ullberg, 1963) and the follicles and CL, the decidual uptake also seen in mice at late gestation may be compared with that of $3 \beta$-hydroxysteroid dehydrogenase described earlier in rats and mice (Deane et al., 1962; Botte et al., 1966). Appelgren (1967) described an intense accumulation of pregnenolone in the mouse decidua, especially in the cells surrounding the maternal blood lacunae. Botte et al. (1966) found $17 \alpha$ - and $17 \beta$-hydroxysteroid dehydrogenase in the yolk-sac endoderm where cadmium also accumulated.

\section{Ovary}

It is known that ovariectomy causes fetal resorption (before Days 15 to 16) or abortion (later) in the mouse (Harris, 1927). Removal of the CL also results in termination of pregnancy (Parkes, 1928) and progesterone will maintain pregnancy in castrated rabbits (Wu \& Allen, 1959).

The accumulation of cadmium in the CL and follicles, especially in the thecal cells, resembles that of pregnenolone, and cholesterol (which also accumulates in the interstitium) (Appelgren, 1967). Appelgren found $3 \beta$-hydroxysteroid dehydrogenase especially in the CL and in the follicular thecal cells. These similarities may indicate that cadmium accumulation is dependent on an affinity for the steroid-producing enzyme systems. Cadmium, in addition, decreases the activity of cytochrome P-450 (Unger \& Clausen, 1973) which is involved in steroid biosynthesis. Cadmium intoxication leads to reversible damage to the ovary (bleeding and follicular atresia) (Kar et al., 1959; Kaul \& Ramaswami, 1970) and an irreversible injury of the testes (Parrízek, 1957). This has been suggested as being secondary to injuries to the vessels (Chiquoine, 1964; Gunn et al., 1966; Johnson, 1969), but it is also known that cadmium influences the testicular androgen production in vitro in trout (Sangalang \& O'Halloran, 1973).

Changes in the gonadotrophic cells of the adenohypophysis, have been described as a result of 'cadmium castration' (Allanson \& Deanesly, 1962; Girod, 1964; David \& Ramaswami, 1971). It is probable, however, that the changes are partly a direct effect due to the accumulation of cadmium.

This study does not conclusively determine the site of teratogenic action of cadmium. It illustrates many sites of accumulation, the significance of which for the developing fetus may be summarized as follows. (1) The heavy accumulation in the embryonic gut wall in early gestation makes probable a direct effect on the embryo. (2) The decidual and placental uptake indicates that the maternalembryonic relationship, and, hence, embryonic nutrition, may be disturbed. (3) The ovarian accumulation may also disturb steroid synthesis leading to an interruption of pregnancy.

\section{AGKNOWLEDGMENT}

This investigation was supported by a grant from the Swedish Medical Research Council (B75-14X-2876-06C). 


\section{REFERENCES}

Abramovich, D.R. (1970) Fetal factors influencing the volume and composition of liquor amnii. $\mathcal{J}$. Obstet. Gynaec. Br. Commonw. 77, 865-877.

Allanson, M. \& Deanesly, R. (1962) Observations on cadmium damage and repair in rat testes and the effects on the pituitary gonadotrophs. $\mathcal{F}$. Endocr. 24, 453-462.

Antonowicz, J., Chang, S.K. \& Grand, R.J. (1974) Development and distribution of lysosomal enzymes and disaccharidases in human fetal intestine. Gastroenterology 67, 51-58.

AppezGren, L.-E. (1967) Sites of steroid hormone formation. Autoradiographic studies using labelled precursors. Acta physiol. scand. Suppl. 301, 1-108.

BARR, M., JR (1973) The teratogenicity of cadmium chloride in two stocks of Wistar rats. Teratology 7, $237-242$.

Becker, R.F., Windle, W.F., Barth, E.E. \& Schulz, M.D. (1940) Fetal swallowing, gastro-intestinal activity and defecation in amnio. An experimental roentgenological study in the guinea pig. Surgery Gynec. Obstet. 70, 603-614.

BERGSTRÖM, S. (1972) Histochemical localization of acid uterine aminoacylnaphthylamidases in early pregnancy and in different hormonal states of the mouse. 7. Reprod. Fert. 30, 177-183.

BerLin, M. \& Ullberg, S. (1963) The fate of $\mathrm{Cd}^{109}$ in the mouse. An autoradiographic study after a single intravenous injection of $\mathrm{Cd}^{109} \mathrm{Cl}_{2}$. Archs envir. Hlth 7, 686-693.

Botte, V., Materazzi, G. \& Chieffi, G. (1966) Histochemical distribution of $3 \beta$-hydroxysteroid dehydrogenase and $17 \alpha$ - and $17 \beta$-hydroxysteroid dehydrogenase in the placenta and foetal membranes of the rat. F. Endocr. 34, 179-183.

Boyer, C.C. (1953) Chronology of development for the golden hamster. F. Morph. 92, 1-38.

Brambell, F.W.R. \& Hemmings, W.A. (1949) The passage into the embryonic yolk-sac cavity of maternal plasma proteins in rabbits. 7. Physiol., Lond. 108, 177-185.

Ghaube, S., Nishimura, H. \& Swinyard, C.A. (1973) Zinc and cadmium in normal human embryos and fetuses. Archs envir. Hith 26, 237-240.

CHiquoine, A.D. (1964) Observations on the early events of cadmium necrosis of the testis. Anat. Rec. $149,23-35$.

DAvid, G.F.X. \& Ramaswami, L.S. (1971) Changes observed in the FSH and LH cells of the adenohypophysis of Presbytis entellus following cadmium induced testicular necrosis. Experientia 27, 342-343.

Deane, H.W., Rubin, B.L., Driks, E.C., Lobel, B.L. \& Leipsner, G. (1962) Trophoblastic giant cells in placentas of rats and mice and their probable role in steroid-hormone production. Endocrino$\log y$ 70, 407-419.

Degenhardt, K.-H. \& Kleinebrecht, J. (1971) Principles in teratology. Adv. Biosci. 6, 547-560.

DenCKeR, L. \& UllberG, S. (1973) Uptake and distribution of drugs in the fetus. Teratology 8, 218-219, Abstr.

FERM, V.H. (1971) Developmental malformations induced by cadmium. Biol. Neonate 19, 101-107.

FERM, V.H. \& Carpenter, S.J. (1967) Teratogenic effect of cadmium and its inhibition by zinc. Nature, Lond. 216, 1123.

Ferm, V.H., Hanlon, D.P. \& URBan, J. (1969) The permeability of the hamster placenta to radioactive cadmium. F. Embryol. exp. Morph. 22, 107-113.

GaLe, T.F. \& Ferm, V.H. (1973) Skeletal malformations resulting from cadmium treatment in the hamster. Biol. Neonate 23, 149-160.

Girod, C. (1964) Etude des cellules gonadotropes antéhypophysaries du Singe Macacus irus F. Cuv., après administration de chlorure de cadmium. C. r. Séanc. Soc. Biol. 158, 948-949.

Gunn, S.A., Gound, T.C. \& Anderson, W.A.D. (1966) Protective effect of thiol compounds against cadmium-induced vascular damage to testis. Proc. Soc. exp. Biol. Med. 122, 1036-1039.

HAFEz, E.S.E. (1964) Uterine and placental enzymes. A review. Acta endocr., Copenh. 46, 217-229.

HARris, R.G. (1927) Effect of bilateral ovariectomy upon the duration of pregnancy in mice. Anat. Rec. 37, 83-93.

Hewitt, E.J. \& Nigholas, D.J.D. (1963) Cations and anions: inhibitions and interactions in metabolism and in enzyme activity. In Metabolic Inhibitors, Vol. II, pp. 311-436. Eds. R. M. Hochster and J. H. Quastel. Academic Press, New York.

Johnson, M.H. (1969) The effect of cadmium chloride on the blood-testis barrier of the guinea-pig. 7. Reprod. Fert. 19, 551-553.

KAR, A.B., DAs, R.P. \& KARKUN, J.N. (1959) Ovarian changes in prepuberal rats after treatment with cadmium chloride. Acta biol. med. germ. 3, 372-399.

Kaul, D.K. \& Ramaswami, L.S. (1970) Effect of cadmium chloride on the ovary of the Indian desert gerbil, Meriones hurrianae Jerdon. Indian F. exp. Biol. 8, 171-173.

KeNch, J.E. \& GuBB, P.J.D. (1970) The activity of certain enzymes in cadmium-poisoned chicks. Biochem. F. 120, 27P. 
Kjeliström, T., Friberg, L., Nordberg, G.F. \& Piscator, M. (1971) Further considerations on uptake and retention of cadmium in human kidney cortex. In Cadmium in the Environment, pp. 140-148. Eds. L. Friberg, M. Piscator and G. Nordberg. C.R.C. Press, Cleveland.

Langman, J. (1969) Medical Embryology, 2nd edn. Williams \& Wilkins, Baltimore.

Lindquist, N.G. \& Ullberg, S. (1971) Distribution of the herbicides 2,4,5-T and 2,4-D in pregnant mice. Accumulation in the yolk sac epithelium. Experientia 27, 1439-1441.

Lzoyd, J.B. \& BEck, F. (1969) The mechanism of teratogenic action of trypan blue. In Teratology. Int. Congr. Ser. No. 173, pp. 145-151. Eds. A. Bertelli and L. Donati. Excerpta Medica Foundation, Amsterdam.

Luais, O.J., Lucis, R. \& ATERMan, K. (1971) The transfer of 109-cadmium and 65-zinc from the mother to the newborn rat. Fedn Proc. Fedn Am. Socs exp. Biol. 30, 238, Abstr.

Merker, H.-J. \& Villegas, H. (1970) Elektronenmikroskopische Untersuchungen zum Problem des Stoffaustausches zwischen Mutter und Keim bei Rattenembryonen des Tages 7-10. Z. Anat. EntwGesch. 131, 325-346.

Mori, C. (1956) A study on the intrauterine selfmovement of early human fetus by hysteroscopy and its recording on the film. F. Fap. obstet. gynaec. Soc. 3, 374-388.

Nordberg, G.F. (1972) Cadmium metabolism and toxicity. Experimental studies on mice. Ph.D. thesis, Karolinska Institute, Stockholm, Sweden.

Paḱzizer, J. (1957) The destructive effect of cadmium ion on testicular tissue and its prevention by zinc. 7. Endocr. 15, 56-63.

Paḱízek, J. (1964) Vascular changes at sites of oestrogen biosynthesis produced by parenteral injection of cadmium salts: the destruction of placenta by cadmium salts. F. Reprod. Fert. 7, 263-265.

Paḱízek, J. (1965) The peculiar toxicity of cadmium during pregnancy-an experimental 'toxaemia of pregnancy' induced by cadmium salts. 7. Reprod. Fert. 9, 111-112.

Parkes, A.S. (1928) The physiology of ovarian activity. Biol. Rev. 3, 208-260.

Rugh, R. (1968) The Mouse. Its Reproduction and Development. Burgess Publishing Co., Minneapolis, Minnesota.

Sangalang, G.B. \& O'Halloran, M.J. (1973) Adverse effects of cadmium on brook trout testis and on in vitro testicular androgen synthesis. Biol. Reprod. 9, 394-403.

Scharpf, L.G., Jr, Hill, I.D., Wright, P.L., Plank, J.B., Keplinger, M.L. \& Calander, J.C. (1972) Effects of sodium nitrilotriacetate on toxicity, teratogenicity and tissue distribution of cadmium. Nature, Lond. 239, 231-234.

Schroeder, H.A. \& Mitchener, M. (1971) Toxic effects of trace elements on the reproduction of mice and rats. Archs envir. Hlth 23, 102-106.

Ullberg, S. (1954) Studies on the distribution and fate of $\mathrm{S}^{35}$-labelled benzylpenicillin in the body. Acta radiol., Suppl. 118, 1-110.

Ullberg, S. (1958) Autoradiographic studies on the distribution of labelled drugs in the body. In Proc. 2nd U.N. Int. Conf., Peaceful Uses of Atomic Energy, Geneva 24, 248-254.

Ulloerg, S. (1972) Autoradiography in fetal pharmacology. In Fetal Pharmacology, pp. 55-73. Ed. L. O. Boréus. Raven Press, New York.

Unger, M. \& GLAUSEN, J. (1973) Liver cytochrome P-450 activity after intraperitoneal administration of cadmium salts in the mouse. Envir. Physiol. Biochem. 3, 236-242.

Webs, M. (1972) Persistence of stored $\mathrm{Cd}^{2+}$ in the livers and kidneys of female rats during pregnancy. 7. Reprod. Fert. 30, 99-103.

Wu, D.H. \& Allen, W.M. (1959) Maintenance of pregnancy in castrated rabbits by 17-alphahydroxy-progesterone caproate and by progesterone. Fert. Steril. 10, 439-460. 